MedieKultur | Journal of media and communication research | ISSN 1901-9726

Article - Theme section

\title{
Online kinship
}

Social media as a site for challenging notions

of gender and family

\section{Rikke Andreassen}

MedieKultur 2016, 76-92

Published by SMID | Society of Media researchers In Denmark | www.smid.dk The online version of this text can be found open access at www.mediekultur.dk

\begin{abstract}
The article shows how the technology of social media sites facilitates new kinds of kinship. It analyzes how 'donor families' - i.e., families in which the children are conceived via sperm and/or egg donations - negotiate kinship, family formations and gender when connecting with each other online. Family formation and parenting are closely connected with gender and gender norms, and online donor families, therefore, offer an opportunity for understanding gender and gender formations in contemporary times and contemporary media. By analyzing commentary threads of a Facebook group connecting donor families as well as interviews with users of this Facebook group, the article shows how the affordances of social media, especially the Facebook application for smart phones, are central to the formation and maintenance of new kinship relations. Furthermore, the article illustrates how conventional practices regarding gender and families on one hand are challenged by the creation of new types of families, while simultaneously being maintained in discussions about choice of donor. Here, a longing for traditional family values seems to run underneath the discussion between members of these new families.
\end{abstract}

\section{Keywords}

Family, kinship, donor families, gender, social media, Facebook 


\section{Introduction: Donor families and social network sites}

Over the past decade, an increasing number of 'alternative families' has emerged. Today, single (heterosexual and lesbian) mothers, lesbian couples and infertile heterosexual couples create families with assistance from a blooming fertility industry (Dahl \& Payne, 2014, p. 13). As a result, thousands of families now have a history of conceiving via sperm or egg donation. In Denmark, almost one out of ten babies is the result of a fertility treatment (Okkels, 2014). There are multiple reasons for this high number; one is the extremely low sperm quality of Danish men (Jørgensen et al., 2001, pp. 1015f.; Jørgensen, 2012, p. 8). Another reason is the liberal Danish law, providing Danish lesbian couples and single women with state-funded fertility treatment. At the same time, Denmark has one of the world's highest Internet penetrations - namely, 97 percent (Internet World Stats). Furthermore, the social network site Facebook is very popular among Danes, of whom more than 3,000,000 use Facebook (out of a population of 5,600,000) (Internet World Stats; see also Jensen \& Tække, 2013, p. 11). Therefore, it is not surprising that several donor families have connected with each other on the Internet and on Facebook. This article explores how donor families from Denmark, Sweden and Norway connect with each other online. Through a Facebook group, they form a community, discuss 'donor parenthood' and connect with 'donor siblings'.

It is not permitted to know the identity of a sperm or egg donor in Denmark. ' However, one receives a donor number or name with respect to donor sperm. Via this number/ name, the parent of the donor child can connect with other parents who also have children from the same donor number/name. The connection of these donor siblings opens up new contours of kinship (Hertz \& Mattes, 2011, p. 1130). This article is interested in exploring how the intersections of social media and kinship potentially transform family formations and gender constructions. Family formation and parenting carry strong connotations of gender and gender norms; analyzing this area, therefore, offers a great opportunity for understanding gender and gender formations in contemporary times and contemporary media. Prompted by questions of how social media contribute to new kinship formations as well as how these new donor families lead to new (potentially, revolutionary) family forms and, finally, what consequences for the understanding of kinship and gender roles such families might have, this article investigates the narratives and negotiations of family in and around the Facebook group. As discussions concerning the choice of sperm donors dominate the Facebook group, this article analyses these discussions in order to provide insights into broader questions regarding gender and kinship constructions.

\section{State of the art - situating the article}

This article places itself in the scholarly intersections of kinship studies, social media studies and gender studies. As all three fields are vast, what follows is not an exhaustive state of the art but rather an overview aiming at situating this specific article. Kinship studies cover broad areas of scholarship, including trans-national adoption (e.g., Myong, 2009; Eng, 2010), 
reproduction practices (e.g., Franklin, 2009; Franklin \& Ragone, 1998) and queer families (e.g., Mamo, 2007; Dahl, 2014). Furthermore, with growing international mobilization, kinship studies have lately witnessed an increased focus on globalized reproduction as consumption (e.g., DasGupta \& DasGupta, 2010; Nebeling \& Myong, 2015). Like this article, kinship studies have investigated how family and gender norms can be challenged or naturalized though kinship (e.g., Thompon, 2005; Mamo, 2007). For instance, in her analysis of ultrasound examinations of pregnant women, Kroløkke (2011) has shown how gender, sexuality and family norms are constructed rather traditionally pre-birth. In this article, I explore how social media potentially create new kinship relations and how gender roles are negotiated within these new relations. Similarly, kinship studies have investigated how new reproductive technologies (and, to a lesser extent, new media technologies) transform and challenge kinship and relatedness (Kroløkke et al., 2016, p. 2). Examples of the latter, relevant for this article, are Hertz and Mattes (2011) and Hertz (2009), who analyze how donor siblings engage with one another via the Internet. They argue that online options for connecting biological offspring with one another open up new understandings of kinship. In this light, I want to investigate potential new meanings of kinship and family formations and potential new meanings of gender. The media site (Facebook) analyzed in this article is quite different from the online Donor Sibling Registry used to connect donor siblings in Hertz and Mattes' analysis. Facebook is interactive, and Facebook groups take shape and develop in accordance with members' activities and discussions. The Donor Sibling Registry is website that provides access to information; it is characterized by one-way communication, and interactions are limited to financial transactions (one must pay to receive information about potential donor siblings).

Social media is characterized by a breakdown of the traditional producer-consumer relationship. Thus, interactivity and user-generated content flourish here and have influenced our daily lives over the previous decade. Consequently, social media have gained much scholarly attention (e.g., Ellison and boyd, 2013; van Dijck, 2013; Mandiberg, 2012). Ellison and boyd (2013, pp. 158f.) argue in favor of labelling social media, such as Facebook, 'social network sites'. Their point is that the term 'social media site' underscores the importance of the network and the social, yet retains the importance of the technology and, hence, how the technology and the affordances of the media influence the social and the network. While some scholars are critical of this underscoring of the social (e.g., van Dijck, 2013, pp. $11 \mathrm{ff}$ ), I find it useful since I am analyzing the social network as well as the technological affordances accompanying the Facebook group. While much scholarly discussion focuses on the status of 'user-generated content' vs. commercially-created or -controlled content (e.g., van Dijck, 2013, pp. 35 f., 45 ff.), my interest here is not to follow this discussion; rather, it is to analyze the content posted by users/members of the Facebook group. Following De Ridder's argument about how personal stories narrated via social media are typically practices of interactivity mediated through a particular media platform (De Ridder, 2015, p. 357), I analyze the content of members' postings. Facebook has changed from being 
an online media used primarily for self-representation (Thumin, 2012) and the creation of networks to becoming increasingly also a media tool for sharing videos, news articles, etc. (Jensen \&Tække, 2013, p. 10; Brügger, 2013, pp. 17 ff.). But the Facebook group analyzed here has remained rather traditional. It continues to be used primarily for creating networks through (self-representative) textual and visual postings. As mentioned previously, Facebook is very popular in Scandinavia; and, worldwide, Denmark is one of the countries in which the use of Facebook is most widespread (Jensen \& Tække, 2013, p. 11). One consequence of this is that Facebook is a medium used by 'ordinary' people; hence, the Facebook group analyzed in this article can provide an understanding of how 'ordinary' people narrate their personal stories as everyday practices. Discussion has taken place about whether social media sites invite to an idealized self-representation (e.g., Manago et al., 2008), but surveys have also shown that individuals present themselves on Facebook in the same way they present their 'offline' self (Back et al., 2010, p. 373). I choose not to enter into this discussion but interpret the Facebook narratives analyzed here as ordinary, everyday narratives. The Facebook group connecting donor siblings is an illustration of how emotions and social media intertwine in contemporary online practices. Here, Facebook is not simply a platform that transmits emotions. Rather, emotions and affectivities emerge and are cultivated through users' online activities and interactions. This article, therefore, also situates itself within the literature concerned with the intersections between social media sites and emotions/affect (e.g., Kuntsman \& Karatzogianni, 2012; Garde-Hansen \& Gorton, 2013).

Finally, this article situates itself within poststructural gender and queer studies. In order to understand the narratives of family and gender circulated in empirical sources, the article combines queer theorist Judith Butler's notions of gender as performative iterations (Butler, 1999) with gender historian Joan Scott's idea about identities as 'fantasy echoes' (Scott, 2001). This combination enables a broad understanding of gender constructions as discursively produced; it supplies Butler's more external focus on stylizations of bodies with Scott's more internal fantasies and longings. Butler has illustrated how gender and sexuality are performative acts and how individuals construct the categories of gender and sexuality through these performances (Butler 1999, pp. 43f.). For this article, I apply Butler's ideas of performativity to the Facebook group, since the group's online interactions can be interpreted as performances. Group members perform gender, sexuality and family via their repeated narrations, utterances and arguments about family formations. Butler has argued that Simone de Beauvoir's famous sentence 'One is not born, but rather becomes, a woman' can be interpreted rather radically as an understanding of gender (and womanhood) as a set of norms that can only exist if one continuously exercise them (Butler, 1998, p. 29). Butler takes this further in Gender Trouble (1999), where she argues that gender, e.g., womanhood, is an active, iterative process. She has famously written, "Gender is the repeated stylization of the body, a set of repeated acts within a highly rigid regulatory frame that congeal over time to produce the appearance of substance, of a natural sort of being" (Butler, 1999, pp. 43f.). These acts are often performed - and understood - within 
the heterosexual matrix (Butler, 1999, p. 9ff.) in which 'women' and 'men' - 'femininity' and 'masculinity' - are viewed as binary oppositions and a coherent gender requires a stable heterosexuality (Butler, 1999, p. 30).

Scott is most famous for her notion of 'gender as an analytical category' (Scott, 1999, p. 42). She has argued that "gender is... a social category imposed on a sexed body" (Scott, 1999, p. 32), which "provides a way to decode meaning and to understand the complex connections among various forms of human interactions" (ibid., pp. 45f.). In other words, gender - which, as a social category, is constantly changing - can be applied analytically to understand changes and interactions in society. While Scott has used the category of gender to understand historical processes of privileges, I use gender in this article to understand and nuance the discussions taking place within the Facebook group. Scott has introduced the term 'fantasy echo' (Scott, 2001), which I find useful for understanding family constructions among donor families. According to Scott, identities often take form as 'fantasy echoes'. She applies the term to illustrate how historians tend to impose preestablished characteristics onto individuals; they categorize them according to presumed, fixed identities (such as 'women' or 'workers'). I use her term to analyze the identities and imaginaries about identities that circulate within the online narratives of donor families, e.g., the 'father'.

Queer anthropologist Ulrika Dahl reminds us that kinship is a site for fantasies as well as political longing and struggle (Dahl, 2014, p. 143). She argues in favor of analyzing 'failures' of kinship, since such 'failures' can provide insights into understandings of kinship and belonging (ibid., pp. 145 ff., 164). For this article, I use 'failures' of kinship as a lens to throw light on norms of gender and family. I am interested in combining Dahl's focus on 'failure' and family with Butler's focus on gender and heterosexuality. Whereas Butler argues that heterosexuality is a foundation (and prerequisite) for a coherent and recognizable gender identity (Butler, 1999, p. 30), I argue - with Dahl's 'failure' in mind' - that coupledom and the nuclear family might be a foundation (and prerequisite) for a coherent, recognizable (and, hence, 'non-failed') family identity.

\section{Methodology, empirical sources and terms}

The empirical sources for this article consist of analysis of the Facebook group and in-depth interviews with 11 people active in this Facebook group. The interviews are so-called openended interviews, a type of interview that allows the interviewee to talk freely and ascribe meaning to what s/he says; such interviews are often used when trying to understand life histories (Silverman, 2006, p. 110). Methodologically, I am inspired by feminist interview techniques (Hesse-Biber, 2006; DeVault \& Gross, 2006); while most scholars acknowledge that knowledge produced through an interview is co-created between the interviewer and interviewee (Silverman, 2006, p. 112; Brinkmann \& Kvale, 2015, p. 63), feminist interviewers are especially concerned with the relationship and hierarchy between the interviewer 
and interviewee (Hesse-Bieber, 2006, p. 128). Early feminist interviewers, e.g., Oakley (1981), argued that the interviewer should share as much of herself and her personal story as the interviewee did in order to break down the hierarchy between the two. While I do not believe that sharing biographies necessarily eradicate hierarchies, I find that it does increase reciprocity. I find that sharing my own experiences of family and kinship creates a bond of trust and understanding between me and the interviewees. The interviews are all between 1-2 hours long; all of them were face-to-face (except one that took place over the phone). They were all recorded and transcribed, which ensures that the interviewees' own voices are represented. After having transcribed and re-listened to all interviews, some common themes were identified; these are themes that all interviewees talked about and positioned themselves in relation to. This article takes its point of departure with the theme: 'choice of donor'. The interviews are analyzed qualitatively. I draw upon Joan Scott's notions of experience as discursively constructed and, hence, understand experiences (and interviews) as narratives about one's subject positions rather than as testimonies of 'truth' (Scott, 1992, pp. 24 ff.). The interviewees were located through an advertisement on the 'Donor Facebook group', followed by the 'snowballing' method in which interviewees assist in recruiting other interviewees (Russel, 2006, p. 192). All the interviewees are women, just as the absolute majority of the group members are women. I visited the interviewees in their homes, except for one woman whom I met at her university. The women represent different family formations: Some are heterosexual, self-chosen single mothers ${ }^{2}$ (3); one is a lesbian, self-chosen single mother (1); some are divorced and share their child(ren) with their ex-partner (3); some are in relationships (lesbian relationships) (2); and some are adult 'donor children' (2). Demographically, they are scattered all over Denmark, inhabiting the capital, small cities and rural areas; their ages range from the early twenties to the early fifties. The majority of them have a professional bachelor degree education (e.g., nurse); some have no formal education; one has a higher university education; and one is a university student. While the 11 qualitative interviews are not representative of the whole 'donor group', they do provide detailed insights into the practices and experiences of the group's members. Furthermore, the women's gender, family situation, educational level, age and demographic setting seem to mirror the 'donor group' as a whole.

I have been a member of the 'donor group' for more than three years during which I have followed and participated in its discussions and knowledge-sharing. I joined the group because I was interested in the group's knowledge-sharing about non-normative families. My analysis of the 'donor group' therefore builds on participatory observations (Emerson, Fretz, \& Shaw, 2001) and netnographic observation (Kozinets, 2015). My participation as an active member of the group provides me with an embedded understanding of the group (Hine, 2015, p. 55). When I decided to use the group as a case study, i.e., when I moved from being an ordinary member to a researcher, I posted a message on the wall of the group explaining my position. Here, I wrote that I was a member of the group and that I wanted to do research within the group. I made my research interest public to the group. I have 
received only positive comments about this 'coming out' as a researcher from other members of the group. Markham has described how researchers can struggle with challenges of privacy when researching the Internet, where privacy is ambiguous (Markham 2012, pp. 336f.). This points to the practices of referring, analyzing and representing statements uttered online - for instance, in Facebook groups. Unlike an interview, the Facebook group provides information that has not been given to me (the researcher) in confidence (see also Kozinets, 2015, p. 140). One might argue that some members of the group might not want me to quote them or conduct research within the group even though they have not stated so specifically. Some members might also initially express support for my research and then feel differently later. Due to this possibility, Markham advocates that researchers "make informed decisions about their practice on a case-by-case basis" (ibid., p. 337). I tried to do so by clearly stating my role as a researcher within the group, as described above. Furthermore, in order to protect all members, I have chosen to ensure anonymity for all. Thus, I have chosen to call the Facebook group the 'donor group' instead of providing its real name, and I replace names of interviewees and Facebook users with fictional names in order to render the individuals anonymous. Similarly, I do not provide the exact date but only the month and year for an uttered statement.

In addition to the interviews, I carry out a longer qualitative analysis of the donor group's discussion threads; threads are chains of comments written by group members as a response to a posted statement or question. Through my engagement with the Facebook group, it has become clear to me how debates and discussion about the choice of donor repeatedly emerge within the group. The choice of donor appears to be pivotal in discussions as well as narrations about forming donor families. Threads, therefore, provide entries into understanding how family formations are negotiated within the group, and they will, therefore, be at the center of my analysis. Often, these Facebook threads contain 25-55 comments, but some generate more than hundred comments. As a result, the threads constitute a vast amount of empirical material. For the analyses here, I have included 10 threads with approx. 600 comments altogether; these have taken place within the previous year (from the fall of 2014 to the spring of 2015). The threads are analyzed qualitatively as text analysis. Like the interviews, they have been categorized according to themes dominating the discussions. When I cite from the discussions, I translate the comments from Danish/Swedish/Norwegian into English; in my translation, I try to remain as close to the original text as possible. Due to the nature of Facebook, where people often write and post comments without previous editing, the sentences are often grammatically wrong, words are misspelled and punctuation is used incorrectly. While I try to keep the syntax and sentence structure close to the original text, I have chosen to correct the misspellings and punctuation errors in order to ease the reading of this article. I use the term 'donor families' and 'donor children' because those are the terms the majority of participants use to describe themselves and their families. 


\section{Anonymous vs. open donor}

The majority of donor children in Denmark and elsewhere are conceived through sperm donation. Sperm donations figure into three categories: 'anonymous donor', 'donor with extended profile' and 'open donor' (also called 'known donor'). With an 'anonymous donor', the parents and the future child only have access to limited information about the donor, such as race, height, weight, hair and eye color. For the 'donor with extended profile', the family has a more detailed donor profile including information about the donor's education, artistic abilities, hobbies, etc., as well as baby pictures and a voice recording of the donor. For both types of donors, the future child cannot obtain any information about the identity of the donor. As for the 'open donor', however, the future child may retrieve information about the identity of the donor when s/he turns 18 years old. Much discussion about the choice of donor in the 'donor group' is initiated by a post in the form of a question as the example below illustrates:

\footnotetext{
I am in a dilemma. I have been inseminated once without success and that was with anonymous sperm. Now I have to start again [...] and I now begin to doubt. Should I choose a NON-anonymous so my hopefully future child has an option to choose when she/he turns 18 to get information about who the father is? My first thought was that it was easier with an anonymous because then there is nothing 'to look for' [...] But I don't want to deny my child the knowledge of where she/he comes from? (Trine, Nov. 2014).
}

This inquiry, like other similar inquiries about choice of donor, received numerous responses. Several members argue in favor of choosing an open donor: "I would without doubt choose an open donor, so that the child could choose if it wanted to know more" (Camilla, Nov. 2014). Similarly, another member states, "For God's sake, open donor. Then you have a choice in the future" (Tanja, Nov. 2014). Even though the 'donor group' is rather large with more than 2,000 members, it is often the same core members who actively participate in the different debates; these members often repeat their arguments and experiences in different posts. Tanja, cited above, repeats her argument in favor of an open donor in another post in which she also elaborates on the reason behind her argument. "For God's sake [choose an] OPEN [donor]. I have an anonymous donor [...]. My son frequently cries because he will not be able to see his father. If you choose an open, you will have a choice in the future. I don't have that!" (Tanja, Feb. 2015). Similarly, another member argues, "I have a son by a known [open] egg donor. I could never make myself eliminate the child's chances of finding the donor. If he needs answers [from the donor] to his questions, then it will not hurt my pride or anything like that to help him get in contact with her" (Theresa, Nov. 2014). Many members who argue in favor of an open donor use the argument of providing their children with choice, i.e., the child should have the option of knowing the identity of the donor when s/he turns 18. Some members express understanding towards parents' various needs: "You are the only one who can decide what is right for you. Personally, I have chosen an open [donor] because I find that my child should have the option [of contact- 
ing the donor when he is 18] if he wishes" (Laura, Nov. 2014). By contrast, other members advocate more harshly in favor of their preference without leaving much room for other parents' choices: "[I] would anytime recommend an OPEN donor, i.e., NOT anonymous [...] I feel sorry for those children who don't get the choice and option. [I] don't find that it is up to us as parents to make that decision [...] I would NEVER deprive my son of that option" (Anne, Nov. 2014). In the same tone, another member states, "Without passing judgment, I could never deprive my future child of her/his right to know her/his biological origin" (Christina, Nov. 2014). Despite her opening phrase "without passing judgment", she clearly does pass judgment, condemning parents who choose anonymous donors and arguing that they are depriving their children of rights. Such comments indirectly accuse parents who choose anonymous donors of letting their children down and depriving them of rights or important options. One can interpret this as an attempt to discipline other parents to perform a specific form of parenting. Hertz (2009, p. 166) argues that there is surveillance between mothers with donor siblings when they engage in potential kin relations with one another; similarly, there seems to be surveillance as well as disciplining between the mothers in the 'donor group'. The woman posting the question writes, "My first thought was that it was easier with an anonymous [donor]", but this idea of 'taking the easy way' is being framed as a wrong way of engaging in motherhood. Drawing on Butler's notion of gender as a set of norms (Butler, 1998, p. 29), one can argue that, within the 'donor group', the correct way of doing motherhood is choosing an open donor; this choice signals that the mother prioritizes her child's future needs over her own wishes. Such motherhood can be interpreted as a traditional, self-sacrificing female behavior in which the mother thinks of her child/family before she thinks of herself. Choice of donor, which can be considered very personal, becomes a topic for general discussion within the 'donor group'; through Facebook, constructions of kinship and parenthood are negotiated between a series of actors instead of simply by one's own family.

\section{The missing father and failures}

While arguments about the well-being of (future) children dominate the discussions, there is another argument that also seems to carry heavy weight: that is the argument of 'a present father'. One member writes, "[The choice of donor] depends on whether you are single or not. Whether you do it alone or together with a partner. I did it with my boyfriend and it is an anonymous donor, and we are having no. 2 with the same [donor]" (Karen, Nov. 2014). The woman who had originally posted the question about choice of donor agrees with the importance of father partner. She writes, "Karen, I fully agree. If I had a partner, and we were not able to conceive, I think I would also choose anonymous. But if I have a child this way [i.e., alone], she/he should know that she/he is a donor child. But I hope that, at some point in the future, there will be a father (if I get a boyfriend)" (Trine, Nov. 2014). Hertz (2006, p. 165) has shown how a social father can trump a generic father when donor siblings meet; in 
this case, a potential social father apparently trumps the child's future need to know hers/ his generic origin.

'The missing father' seems to be a figure that runs beneath many of the discussions among the members of the 'donor group'. Scott's term 'fantasy echo' (Scott, 2001) is useful for understanding 'the missing father'. The term carries with it a longing, as Scott used it about historians' longing for pre-established identities that can unite people in the past with contemporary people. While Scott has developed the term in a different context than mine, I will argue that the same processes of fantasy, longing and imposed fixed identities upon imaginary characters are at play in the 'donor group'. Here, 'the missing father' is a fantasy of longing that runs through several of the family narratives. Several of the single heterosexual mothers express how they would have preferred to conceive and form a family together with a male partner.

For many years, I had thought about having a child on my own, but I did not because I was waiting to see if some man would show up - but he didn't. I had no doubt that the donor should be open because I would have preferred a known [father] (Sanne, interview, Feb. 2015).

It has cost me great effort to conceive on my own.... To call the fertility clinic was such a transgressive act to me - and it took me two years to do it. ... I thought I was the only nonmarried woman to have a child on her own ... I have always imagined that, if I were to have children, it would be within a nuclear family. I had never imagined that I would be a single mother (Jeanette, interview, March 2015).

The women do not express a longing to have a partner, only to have a father for their child and to form a nuclear family. Some of them explain how they find life easier without a partner. "I am happy with our life here. It is me and my child. It works perfectly. I actually think it would create more trouble if I also had a husband" (Sanne, interview, Feb. 2015). "I like it this way [being a single parent]. I can make all decisions. Honestly, I think it would be more complicated if I had a husband" (Lise, Feb. 2015).

The fantasy echo, therefore, can be interpreted as a longing for a norm (the nuclear family) rather than a longing for a partner. The women express satisfaction at living on their own, while they simultaneously admit to having struggled (and that they continue to struggle) with not living up to their own - and society's - ideals and norms for kinship. Butler points out how norms can only exist if they are continuously repeated (Butler, 1998, p. 29); the norm of the nuclear family continues to exist as a fantasy echo, while the practices of family (kinship without a father) simultaneously challenge the norm. Today, coupledom seems to trump heterosexuality (Dahl, 2014, p. 160); single parents are more marginalized than lesbian couples. For single parents, the lack of a father is not simply connected to failing as a heterosexual woman, whose gender identity can be perceived as less coherent compared to heterosexual women conceiving with their husbands (Butler, 1999, p. 30); it is about 'failing' as a family. This 'failure' is reflected in the longing for a father. Fur- 
thermore, one might argue that the 'failure' is reflected in the arguments for using open donors; here, the possibility of knowing one generic origins can be seen as compensating for the lack of father and nuclear family, as expressed above.

At the same time, the women's families, and their lives without men, can also be interpreted as examples of Butler's so-called 'gender trouble' (Butler, 1999, p. 44). The women create 'trouble' in the traditional family and gender norms when they choose to conceive on their own. But their attitude towards this 'gender trouble' is ambivalent; on one hand, they express being happy with their lives; but, at the same time, the debates about choice of donor bear testimony to the significance ascribed to having a father (and the norm of the nuclear family). While 'gender trouble' has often been described as joyful and celebratory (e.g., Halberstam \& Volcano, 1999), the 'donor group' points to 'gender trouble' and, hence, the act of challenging gender norms and creating new family forms - as being accompanied with longing and ambivalence.

\section{Coupledom and lesbian nuclear families}

Within lesbian donor families, traditional norms also seem to dominate, since couplehood and nuclear families are constructed as ideals. One interviewee explains:

First, we [my wife and I] thought about whether we should have an active father [i.e., a friend who would be the father]. But then we felt: 'No, we are two parents'. Then, we thought about using an open donor. But, then, we felt: 'No, we are two parents'. It was OK to use anonymous sperm because we were already two parents (Alicia, interview, March 2015).

Here, the couple, two parents, dominates at the expense of the child's potential need to find its biological origins. It is the nuclear family (two parents with children) which is framed as an ideal. Dahl argues that same-sex families do not disrupt traditional models of family but rather extend these models (Dahl, 2014, p. 151). Similarly, lesbian donor families do not necessarily dismantle traditional ideals of families; instead, they extend these families to include new types of family members - namely, two mothers and donor-conceived children.

Interpreting gender identity in relation to 'the heterosexual matrix' (Butler, 1999, pp. 9 f.) in which 'sex', 'gender' and 'desire' correspond to heterosexual norms, a lesbian couple can be seen as 'failing' in their sexuality. Therefore, one can argue that, in order to compensate for this 'failure', the lesbian couple aims at living up to traditional norms for creating a family, i.e., staying within a normative nuclear family framework.

One interviewee, Randi, has encountered hostility from other lesbian families because she has connected with her children's donor siblings. 
problems with us being lesbians. But they ask: 'How can you choose to open up the family to strangers. One should not do that'. They feel that connecting with donor siblings becomes a threat to the family. Several of my lesbian friends argue that they would not try to find donor siblings because that would put pressure on the non-biological mother. [...] It is also because they feel it breaks with the ideas of the nuclear family. One thing is that you are a lesbian family, but if you also have all these donor siblings, then it becomes too much (Randi, interview, March 2015).

Here, there is no fantasy echo of a missing father but, rather, a fear of being excluded from the family unit if one is not biologically connected to the children. This points to fundamental questions about the roots of relatedness and constructions of kinship (Franklin \& Ragoné, 1998). The donor siblings underscore this fear since they embody the biological kinship in question. Furthermore, the criticism directed at Randi's family seems to target a perceived 'failure' of not living up to traditional ideals about families, namely, the nuclear family. The criticism involves concerns about causing further 'failings' as a non-traditional family. As Randi expresses it, "one thing is that you are a lesbian family but connecting with donor siblings becomes too much". One way of compensating for the 'failure' of the lesbian family, described above, seems to be to perform the family setting correctly, i.e., to stay within a normative nuclear family.

As illustrated above, the discussions within the 'donor group' are dominated by women. It is not possible to know the identities of online participants since some might be using a nickname or a fictional profile, but these discussions are carried out solely by people using profiles with female names. Hence, the discussions of family and gender take place between women (mothers) via the online forum; by debating choices of donor, the women negotiate motherhood. As shown, negotiations of family and motherhood are carried out in an online space in which individual members of the group discipline one another. As a consequence, one might argue that the online group is not simply a liberating space in which donor families are accepted; the online forum also becomes a setting for maintaining traditional gender roles and family norms by members' idealization of the father and the nuclear family.

Randi's narrative, cited above, points to similar negotiations of meanings with respect to family and kinship; here, different lesbian families with donor-conceived children discuss whether they should locate donor siblings. As an attempt to discipline Randi into living in a nuclear family, her friends frame donor siblings as perils to the non-biological mother and as ideological harmful to traditional family formations. Donor siblings are 'too much'. The lesbians have already stepped outside the norm by constituting a lesbian family; inviting donor siblings into the family becomes too much 'failure' and 'kinship trouble'. These discussions testify to how struggles of kinship might not necessarily take place between donor families vs. non-donor families (or lesbian families vs. heterosexual families) but rather within the community of donor families. 


\section{The affordances of the media}

For some of the mothers, the open donor seems to compensate for the lack of father, as illustrated above, but donor siblings also seem to serve this function. Several of the interviewees explain how they began searching for donor siblings, as they feared their children would feel lonely because they were donor-conceived. One interviewee relates, "I was getting sentimental during the holiday, and I was feeling a bit sad because my child only has me. I decided to search for potential half-siblings because, then, I could provide more family for my child" (Sanne, interview, Feb. 2015). Similarly, another woman explains how the donor siblings compensate for the lack of her son's paternal family: "[Finding donor siblings] is a gift for my son [...]. I feel good about providing him with more family. [Because other than that,] it is only me and my parents, and they are getting older ... I grew up in a large family and family is really important to me; giving him more family for the future is important. Kinship is important. [...] I feel a special connection to the other mothers [of the donor siblings]. I feel we are family (Lise, interview, Feb. 2015). Similarly, Hertz and Mattes (2011, p. 1135) find that one of the main reasons American mothers with donor-conceived children connect with donor siblings is because they want to extend their child's family.

These new family bonds are made possible because of social media sites. While the fantasy echo of the missing father runs through many of the women's narratives and becomes a catalyst for creating a new type of family, it is the technology of social media sites that facilitates the new kinships. The Internet not only makes the connection between donor siblings possible, it also provides platforms for cultivating new family relations once they are discovered. Several interviewees describe how they were directed by Google searches towards the 'donor group' through which they found donor siblings and formed community with other donor families. Once they have located donor siblings, they use online social media sites to develop relationships with the new family members. Typically, the parents of donor children build a relationship with other parents (who have used the same donor) via email or Facebook's Messenger; here, they exchange information about the children and themselves as well as photographs and videos.

Hertz and Mattes (2011, pp. 1143f.) argue that online connections between donor families do not create ties between donor families as close as offline interactions do. Consequently, they rank offline meetings substantially higher than online connections when they measure levels of interaction and family closeness. By contrast, the 'donor group' provides examples of how online connections might be just as important for creating kinship as offline interactions. One interviewee explains how the affordances of social media sites (especially, Facebook and smartphones) have allowed her and other parents to become close by sharing large numbers of photographs.

The media have helped develop our contact and also to maintain that contact. Facebook makes it easy to keep track of the other donor siblings' lives. It becomes a way of maintaining 
the contact. We don't have to write a lot of things, we can just upload a photograph (Lise, interview, Feb. 2015).

Research has shown how family members maintain relationships via online media when separated by migration (e.g., Madianon \& Miller, 2012); in a similar way, these new donor families maintain contact through online media. But whereas members of the migrant families are maintaining their original family ties, the donor families do not have original family ties. Here, the media do not simply maintain an existing family contact but, rather, contribute to developing family ties. As Ellison and boyd (2013, pp. 161ff.) point out, the media technology is central; functions for uploading photographs seem especially vital to connect the donor families with one another. One can interpret the photographs as constituting a shared narrative for the members of the group. As Lise mentions above, the affordances of Facebook and its 'upload photo function', combined with a smartphone, are important. To Lise and the other parents, time and energy are required to arrange physical meetings and to write messages, whereas uploading photographs is fast and easy. She explains how sharing photographs "becomes a normal part of your life" (Lise, interview, Feb. 2015). Her smartphone is an integrated part of her life, and sharing photographs of her child online via her phone becomes her preferred way of interacting with the other donor families. Lise meets physically with two other donor families (who all have children by the same donor) on a regular basis. The families are close, and she considers them family, as mentioned above. While their physical meetings create the foundation of their closeness and sense of family, it is the ongoing, daily online contact through social media sites that cultivates and maintains this closeness and sense of family.

\section{Conclusion}

This article was prompted by the question of how online connections between families with donor-conceived children lead to new kinships and new understandings of family. By analyzing narratives and negotiations of family in and around a Facebook group connecting donor families, the article shows how the social media site Facebook enables new kinship connections that challenge traditional understandings of family and kinship. At the same time, the narratives being performed in the online space within the 'donor group' help maintain normative gender roles and uphold traditional ideals about the nuclear family. Consequently, discussions about family formation can be interpreted as disciplining practices within the 'Donor community'.

In this way, there is a strong ambivalence running through the empirical sources. Women making families without men (single women and lesbian couples) can be interpreted as destabilizing norms of gender and family and, hence, as creating 'gender and family trouble'. In some ways, single women might cause greater 'kinship trouble' than lesbian couples since the lesbians can be seen as extending the nuclear family ideal rather than dismantling it. 'Failures' within kinship can, therefore, be interpreted as 'trouble' and as an escape from 
disciplining norms (Dahl, 2014, p. 165). However, the article shows how these 'failures' and 'troubles' are accompanied with sadness and longing. Whereas Dahl (2014, p. 143) points to queer kinship as a site for fantasies, longings and struggles, this article adds the perspective of queer kinship as a site for fear: fear of exclusion and fear of not living up to existing norms of coupledom and nuclear family formations.

Finally, the article points to the affordances of the media, i.e., social media sites and smart phones, as being of central importance for creating alternative families - not simply because media tools enable connections between families but also because the affordances of the media secure a cultivation and maintenance of the contacts; this enables the contacts to develop into kinship relations.

\section{Notes}

1 However, if one chooses a so-called open donor, the child can get access to information about the identity of the donor when s/he turns 18.

2 'Self-chosen single mother' is defined as a woman who has chosen to become a single parent, i.e., become pregnant with donor sperm.

\section{References}

Back, M., et al. (2010). Facebook profiles reflect actual personality, not self-idealization. Psycho logical Science, 21(3), 372-374.

Brinkmann, S. \& Kvale, S. (2015). InterViews. Learning the Craft of Qualitative Research Interviewing. London: Sage, $3^{\text {rd }}$ edition.

Brügger, N. (2013). Facebooks historie. In Jensen \& Tække (Eds), Facebook. Fra socialt netvæerk til metamedie (pp.17-44). Copenhagen: Samfundslitteratur.

Butler, J. (1990/1999). Gender Trouble. Feminism and the Subversion of Identity. New York: Routledge.

Butler, J. (1998). Sex and gender in Simone de Beauvoir's Second Sex. In E. Fallaize (Ed.), Simone de Beauvoir: A Critical Reader (pp. 30-42). New York: Routledge.

Dahl, U. (2014). Not gay as in happy, but queer as in fuck you: Notes on love and failure in queer(ing) kinship. Lambda Nordica, vol. 3-4, 143-167.

Dahl, U. \& Payne, J.G. (2014). Introduction: (Re)thinking queer kinship and reproduction. Lambda Nordica, vol. 3-4, 11-27.

DasGupta, S. \& DasGupta, S.D. (2010). Motherhood jeopardized: Reproductive technologies in Indian communities. In W. Chavkin, \& J. M. Maher (Eds.), The Globalization of Motherhood. Deconstructions and Reconstructions of Biology and Care (pp.131-153). New York, NY: Routledge.

De Ridder, S. (2015). Are digital media institutions shaping youth's intimate stories. New Media \& Society, 17(3), 356-374.

DeVault, M. \& Gross, G. (2006). Feminist interviewing. In Hesse-Biber, \& Leavy (Eds.), The Practice of Qualitative Research (pp. 173-197). London: Sage.

Ellison, N. \& boyd, d. (2013). Sociality through social network sites. In Dutton (Ed.), The Oxford Handbook of Internet Studies. Oxford: Oxford University Press. 
Emerson, R.M., Fretz, R.I., \& Shaw, L.L. (2001). Participant observation and fieldnotes. In Atkinson, et al.

(Eds.), Handbook of Ethnography (pp. 356-357). Thousand Oaks, CA: Sage.

Eng, D. (2010). The Feeling of Kinship. Durham: Duke University Press.

Franklin, S. \& Ragone, H. (Eds.) (2009). Reproducing Reproduction. Kinship, Power and Technological Innovation. Philadelphia: Pennsylvania University Press.

Franklin, S. (1993) Postmodern procreation: Representing reproductive practice. Science as Culture, 3(4), 522-561.

Garde-Hansen, J. \& Gorton, K. (2013). Emotion Online. London: Palgrave Macmillan.

Halberstam, J. \& Volcano, D. (1999). The Drag King Book. London: Serpent's Tail.

Hertz, R. \& Mattes, J. (2011). Donor-shared siblings or genetic strangers: New families, clans, and the Internet. Journal of Family Issues, Sept. 32, 1129-1155.

Hertz, R. (2009). Turning strangers into kin. Half siblings and anonymous donors. In Nelson \& Garey (Eds.), Who's Watching? Daily Practices of Surveillance among Contemporary Families (pp. 156-174). Nashville: Vanderbilt University Press.

Hesse-Biber, S. (2006). The practice of feminist in-depth interviewing. In Hesse-Biber \& Leavy (Eds.), The Practice of Qualitative Research (pp. 111-148). London: Sage.

Hine, C. (2015). Ethnography for the Internet. London: Bloomsbury.

Jensen, J. \& Tække, J. (Eds.) (2013). Facebook. Fra socialt netvark til metamedie. Copenhagen: Samfundslitteratur.

Jørgensen, N. et al. (2012). Human semen quality in the new millennium. BMJ Open, 2(4).

Jørgensen, N. et al. (2001). Regional differences in semen quality in Europe. Human Reproduction, 16(5), 1012-1019.

Kozinets, R.V. (2015). Netnography. Redefined. London: Sage.

Kroløkke, C. (2011). Biotourist performances. Doing parenting during the ultrasound. Text and Performance Quarterly, 31(1), 15-36.

Krolykke C. et al. (Eds.) (2016). Critical Kinship Studies. London: Rowman and Littlefield.

Kunstman, A. \& Karatzogianni, A. (Eds.) (2012). Digital Cultures and the Politics of Emotions. London: Palgrave Macmillan.

Madianon, M. \& Miller, D. (2012). Migration and New Media. London: Routledge.

Mandiberg, M. (Ed.) (2012). The Social Media Reader. New York: NYU Press.

Markham, A. (2012). Fabrication as ethical practice. Information, Communication and Society, 15(3), 334-353.

Mamo, L. (2007). Queering Reproduction. Durham: Duke University Press.

Manago, A.M. et al. (2008). Self-presentation and gender on MySpace. Journal of Applied Developmental Psychology, 29, 446-458.

Myong, L. (2009). Adopteret - Fortcellinger om transnational og racialiseret tilblivelse. PhD Dissertation, University of Aarhus.

Nebeling, M. \& Myong, L. (2015). (Un)liveabilities. Homonationalism and transnational adoption. Sexualities, 18(3), 329-45.

Oakley, A. (1981). Interviewing women: A contradiction in terms. In H. Roberts (Ed.), Doing Feminist Research. London: Routledge, 30-61.

Okkels, S. (2014, 10 March). Ny forskning: Derfor er fertilitetsbehandling en god forretning. Berlingske Tidende.

Scott, J.W. (1999). Gender and the Politics of History. New York: Columbia University.

Scott, J.W. (2001). Fantasy echo: History and the construction of identity. Critical Inquiry, 27(2), 284-304.

Scott, J.W. (1992). Experience. In Butler \& Scott (Eds.), Feminists Theorize the Political (pp. 22-40). New York: Routledge. 
Article: Online kinship

Silverman, D. (2006). Interpreting Qualitative Data. London: Sage.

Thumin, N. (2012). Self-Representation and Digital Culture. New York: Palgrave-Macmillan. van Dijck, J. (2013). The Culture of Connectivity. Oxford: Oxford University Press.

Rikke Andreassen

Associate Professor, PhD

Department of Communication and Arts

Roskilde University, Denmark

Rikkean@ruc.dk 